\title{
High Prevalence Of Alphaherpes Virus 2 (HSV-2) Positivity In Prisons From Midwest Brazil: A Cross- Sectional Study
}

Nathália Alves Araujo de Almeida

Fundacao Oswaldo Cruz Instituto Rene Rachou

Lyana Rodrigues Pinto Lima

Fundacao Oswaldo Cruz

Marco Antonio Moreira Puga

Universidade Federal de Mato Grosso do Sul

Julio Croda

FIOCRUZ: Fundacao Oswaldo Cruz

Marco Aurelio Horta

Fundacao Oswaldo Cruz

Ana Rita Coimbra Motta-Castro

Universidade Federal de Mato Grosso do Sul

Vanessa Salete de Paula ( $\square$ vdepaula@ioc.fiocruz.br)

Oswaldo Cruz Foudation https://orcid.org/0000-0002-6314-754X

Research article

Keywords: Human herpes virus, seroprevalence, prisoners, epidemiology, Brazil

Posted Date: November 9th, 2020

DOI: https://doi.org/10.21203/rs.2.21986/v2

License: (9) This work is licensed under a Creative Commons Attribution 4.0 International License.

Read Full License 


\section{HIGH PREVALENCE OF ALPHAHERPES VIRUS 2 (HSV-2) POSITIVITY IN PRISONS FROM MIDWEST BRAZIL: A CROSS- SECTIONAL STUDY}

Nathália Alves Araujo de Almeida ${ }^{*}$, Lyana Rodrigues Pinto Lima1, Marco Antonio Moreira Puga ${ }^{2}$, Ana Rita Coimbra Motta de Castro², Marco Aurelio Horta ${ }^{3}$, Vanessa Salete de Paula ${ }^{1}$

${ }^{1}$ Laboratory of Molecular Virology, Oswaldo Cruz Institute/ Fiocruz, Rio de Janeiro, Brazil.

${ }^{2}$ Federal University of Mato Grosso do Sul, Centro de Ciências Biológicas e da Saúde da UFMS, Setor Hemonúcleo, Mato Grosso do Sul, Brazil

${ }^{3}$ Platform NB3, Oswaldo Cruz Institute/ Fiocruz, Rio de Janeiro, Brazil.

Corresponding author: Dr Vanessa Salete de Paula, Oswaldo Cruz Foundation, IOC Av. Brasil 4365-Manguinhos, Pav. Helio e Peggy Pereira B219, 21040-360. Rio de Janeiro, Brazil. Tel (+55 21) 2562-1876

e-mail: vdepaula@ioc.fiocruz.br (VSP) 


\section{Abstract}

Herpes virus 2 (HSV-2) is the main cause of genital herpes, one of the most prevalent sexually transmitted infections (STIs) in the world. STIs are major public health problems in prisons because of the behaviors of prisoners and the presence of other factors that increase the risk of transmission. The present study aimed to estimate the prevalence and risk factors associated with HSV-2 infection at 12 prisons in Mato Grosso of Sul, Brazil. We tested 872 serum samples (732 from males, 140 from females) for anti-HSV$2 \mathrm{IgG}$, and tested the positive samples $(\mathrm{n}=184)$ for anti-HSV-2 IgM. Anti-HSV-2 IgG positivity ( $\mathrm{n}=85,43.1 \%, 95 \% \mathrm{CI}=34.6$ to 40.4$)$. The prevalence of HSV-2 positivity was much greater than reported in the general population of Brazil and in other prison populations worldwide. There was a greater risk of HSV-2 positivity in prisoners who were older, female, unmarried, HIV positive, positive for other STIs, not previously incarcerated, in the same cell with more than 26 individuals, and in those who reported having had genital discharge in the past month, having had a homosexual relationship in recent months, and not using or occasionally not using condoms during sexual intercourse. Further analysis of prisoners with active HSV-2 infections (anti-HSV-2 IgM positivity) indicated that unmarried status and the presence of 26 or more prisoners in the same cell increased the risk for active HSV-2 infection. This study provides important data on HSV-2 seroprevalence in the prison population of Brazil, and identified risk factors associated with HSV-2 infection. These data provide important information needed to implement procedures that better prevent and control of STIs in prison populations.

\section{Keywords}

Human herpes virus, seroprevalence, prisoners, epidemiology, Brazil 


\section{Background}

3

4

5

6

7

8

Individuals living in precarious environments such as prisons, which are typically characterized by poverty, conflict, discrimination, and apathy, often have poor health [1]. In particular, prisoners have a high risk for infectious diseases. Moreover, the confinement and conditions in prisons make it difficult for these individuals to access integrated and effective health care services [2]. Individuals in prisons throughout the world have increased risk for many health problems. When convicted, prisoners in precarious prisons, police stations, houses of detention/correction, and similar institutions are typically exposed to environments with poor sanitary conditions, and they are confined and in close proximity to others with infectious diseases. A recent study described the prison environment as a site with great concentration and amplification of situations and risk factors that facilitate the spread of infections [3]. Many factors favor the spread of infectious diseases among prisoners, such as their idleness, overcrowding, stress caused by incarceration and disruption of social and family ties, poor sanitary conditions, physical abuse, dependence on licit and illicit toxic substances (alcohol and tobacco), handmade tattoos, sharing of piercing-sharps, gestation without prenatal care, and social marginalization [4] [5].

Brazil has the third-largest overall prison population in the world, according to data of the Ministry of Justice. In 2019, there were 729.949 Brazilians in jail [6].

The Human alphaherpesvirus 2 (HSV-2) is primarily responsible for genital herpes, and is widely distributed worldwide [7]. In addition, this virus is efficiently transmitted, has rapid replication, and can remain latent in the sensory nerves for long periods [8]. There are many symptoms of HSV-2 infections, including oropharyngeal, cutaneous, and genital diseases, and encephalitis [9]. The initial infection usually 
manifests as an ulcerative lesion in the genitalia, and is more common in adolescents and sexually active adults [10];[11]; [12]. After an acute primary infection, the virus often remains latent in the sensory ganglia, and may spontaneously re-activate depending on the immune status and genetic predispositions of the patient. Reactivation may lead to recurrent lesions or genital herpes, with manifestations ranging from asymptomatic viral excretions to painful symptomatic blisters [13]; [14]; [15].

The World Health Organization (WHO) estimated that 417 million people aged 15 to 49 years have HSV-2 infections [16]. There is no compulsory notification for HSV2 infections, so data on the prevalence and incidence in Brazil are limited. Researchers believe there is a high rate of HSV infection in Brazil, even though most individuals are asymptomatic. The health ministry estimated that more than $90 \%$ of Brazilians have antibodies against HSV-1 and/or HSV-2, even though the majority have never presented with symptoms [17]. Some behaviors may increase the risk of HSV-2 infection, and these are the same factors that increase the risk of sexually transmitted infections (STI) in general populations: unprotected sexual activity, sexual intercourse with many homosexual or heterosexual partners, sexual violence, unprotected sex between inmates, and intimate visits with prisoners [2]. Given the lack of prevention policies regarding HSV-2 infection in Brazilian prisons, the aim of this study was to estimate the seroprevalence and predictive factors of HSV-2 infection among prisoners from 12 prisons in Midwest Brazil. 
46

\section{$47 \quad$ Ethics}

48

\section{Methods}

This study was approved by the Education and Training Unit of the Federal University of Grande Dourados (CE/UFGD) CAAE 05598912.0.0000.5160 opinion 191.877 and the State Agency of Administration of the Penitentiary System/MS (Agepen/MS). The participants were approached and asked to sign an informed consent form (ICF) which explained the purpose of the study. Emphasis was placed on the confidentiality of each individual's identity and personal information by explaining that only the team of researchers would have access to the information, and that all data would be used exclusively for research purposes.

\section{Study participants and procedures}

This was a multicenter, retrospective, descriptive study, which analyzed observations of primary data and laboratory test results. The study was conducted from March 2013 to March 2014 in 12 prisons (4 for females and 8 for males) from Mato Grosso do Sul, Brazil (Figure 1).

The directors of each penal establishment were contacted to obtain authorization for the team of investigators and for evaluation of logistical needs. Subjects were included if they signed the ICF, authorized the use of samples for research, and provided answers to a questionnaire about certain general factors (age, sex, education, knowledge about sexually transmitted infections, and socioeconomic and behavioral factors that were used to identify risk factors. 
68 Figure 1: Locations of the 12 study prisons in the state of Mato Grosso do Sul, Brazil

69 (adapted from Puga et al, 2017).

70

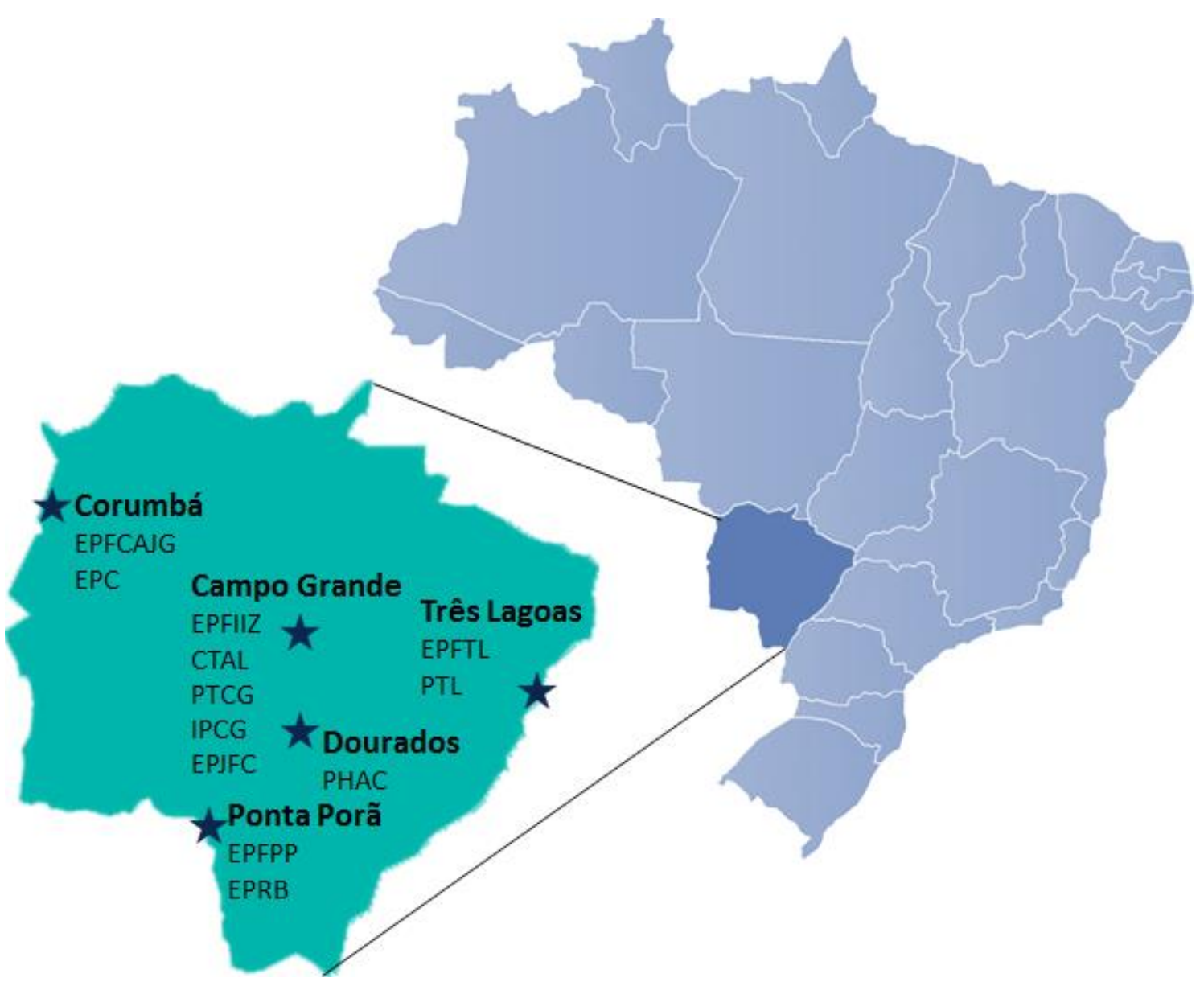

Abbreviations: EPFCAJG, women's penal establishment Carlos Alberto Jonas Giordano; EPFTL, women's penal establishment Três Lagoas; EPFPP, women's penal establishment Ponta Porã; EPFIIZE, women's penal establishment Irmã Irma Zorzi; EPC, penal establishment de Corumba; PTL, penal establishment Três Lagoas; EPRB, penal establishment Ricardo Brandão; CTAL, Centro de Triagem Anoazio Lima; PTCG, penal establishment de Campo Grande; IPCG, penal establishment Campo Grande; EPJFC, penal establishment Jair Ferreira de Carvalho; PHAC, penal establishment Harry Amorim Costa. 
A team of trained health professionals performed the interviews, which were conducted while the prisoners were sunbathing. The interviewers always maintained a safe distance from the interviewees to guarantee the physical integrity of interviewers of the participants. The study subjects were told that participation was voluntary, and they had a right to refuse without any threat of reprisal.

A simple random probability sampling form was used, so that participants were likely to be representative of the overall population, thus ensuring the internal validity of the study. The collected serum samples were sent to the Oswaldo Cruz Foundation, Rio de Janeiro, to be tested for HSV-2.

The number of subjects $(\mathrm{N})$ was determined as: $\mathrm{N}=\mathrm{z}^{2} \times \mathrm{p} \times(1-\mathrm{p}) / \mathrm{e}^{2}$. Where $\mathrm{z}$ is the confidence level based on a standard normal distribution (1.96 for 95\%), $\mathrm{p}$ is the expected prevalence ( 0.113 in the general population, because no data were available for the study population), and e is the maximum acceptable error in the estimate (0.05).

A total of 872 serum samples were examined (732 males and 140 females) from different age groups. All randomly selected individuals where be arrested in a closed regime, over 18 years-old, and provided informed consent. The exclusion criteria were: volunteering to participate without initially being screened, being pregnant, having a mental illness, and being unable to respond to the questionnaire for any reason.

\section{HSV-2 tests}

Serum samples were tested for anti-HSV-2 IgM and anti-HSV-2 IgG using an enzyme-linked immunosorbent assay type-specific glycoprotein C2 gG2 (Euroimmun commercial kit, Luebeck, Germany). The test protocol was followed according to the instructions of the manufacturers, using internal positive and negative controls that were part of the assay kit. 


\section{Data analysis}

The questionnaire data were entered into a database. Inferential statistics using Pearson's $\chi^{2}$ analyses were calculated, and all variables that were significant at the univariate level $(\mathrm{p}<0.05)$ were entered into unadjusted and adjusted logistic regression models to predict the ORs and 95\% CIs for associations with the dependent variable (antiHSV-2 IgG and anti-HSV-2 IgM positivity). Analyses were performed using the RStudio Desktop statistical package.

\section{Results}

\section{Characteristics of the study population}

Analysis of the sociodemographic characteristics of the participating prisoners (Table 1) indicated that a majority were male (84\%), had fewer than 4 years of education $(66.7 \%)$, were married (60\%), and were not users of injection drugs (84\%). Most participants $(82 \%)$ worked before incarceration, and $65 \%$ of women and $94.6 \%$ of men said they were not injectable drug users (IDUs). The average incarceration time was 17 months, and most participants were previously in jail. Analysis of the sexual histories of the participants indicated that $94.1 \%$ were heterosexual, but $11.6 \%$ reported having a previous homosexual relationship. In addition, $34.3 \%$ reported using condoms only sometimes or never during intercourse.

The overall HSV-2 prevalence was $43.1 \%$ (95\% CI: 34.6 to 40.4 ), and the prevalence was greater in females than males $(68 \%, 95 \%$ CI: 8.4 to 10.7 vs. $37 \%$, $95 \%$ CI: 2.54 to 3.07). The HSV-2 females-to-male prevalence ratio was 4.2 (95\% CI: 2.5 to 7.1, $\mathrm{p}<0.001$; Table 1). Moreover, the prevalence of HSV-2 positivity was greater in females than males of all ages, except for those who were 62 years-old or more (Figure 2). 
Table 1: Association of HSV-2 positivity with sociodemographic characteristics, risk factors, and prison variables among male and female prisoners at baseline $(n=872)$.

\begin{tabular}{|c|c|c|c|c|}
\hline Variable & $\mathrm{N}(\%)$ & Missing & OR $(95 \%$ CI) & $P$ value \\
\hline HSV-2 positivity & $375(43.1)$ & & & \\
\hline \multicolumn{5}{|l|}{ Sex } \\
\hline Male & $732(83.9)$ & & 1 & \\
\hline Female & $140(16.1)$ & & $4.2(2.5-7.1)$ & $<0.001$ \\
\hline \multicolumn{5}{|l|}{ Sociodemographics } \\
\hline Age, years, mean \pm SD & $32.04 \pm 10.09$ & & $1.9(1.1-3.3)$ & 0.02 \\
\hline Schooling, less than 4 years & $584(66.7)$ & & $0.4(0.2-0.8)$ & 0.05 \\
\hline \multicolumn{5}{|l|}{ Marital status } \\
\hline Married & $525(60.2)$ & & 1 & \\
\hline Not married & 347 (39.7) & & $1.9(1.5-2.5)$ & 0.04 \\
\hline \multicolumn{5}{|l|}{ Drug history } \\
\hline Non-IDU & $731(83.8)$ & 3 & 1 & 0.04 \\
\hline IDU & $7(0.8)$ & 2 & $0.9(0.6-1.2)$ & 0.3 \\
\hline \multicolumn{5}{|l|}{ Sexual history } \\
\hline Sexual preference & & 4 & & \\
\hline Heterosexual & $845(97)$ & & 1 & 0.12 \\
\hline Homosexual & $23(2.6)$ & & $1.2(0.7-2.0)$ & 0.10 \\
\hline Previous homosexual intercourse & $69(7.9)$ & & $1.3(0.2-5.7)$ & 0.20 \\
\hline Condom use & & 1 & & \\
\hline Always & $296(33.9)$ & & 1 & \\
\hline Sometimes/never & $565(64.7)$ & & $1.9(1.2-2.9)$ & 0.02 \\
\hline \multicolumn{5}{|l|}{ Other Risky behaviors } \\
\hline \multicolumn{5}{|l|}{ History of STI(s) } \\
\hline No & 767 (87.9) & & 1 & \\
\hline Yes & $103(12)$ & 5 & $4.9(1.7-13.5)$ & $<0.001$ \\
\hline \multicolumn{5}{|l|}{ HIV status } \\
\hline Negative & $863(98.9)$ & & 1 & \\
\hline Positive & $9(1)$ & & $2.3(1.4-3.8)$ & $<0.001$ \\
\hline \multicolumn{5}{|l|}{ Presence of genital discharge* } \\
\hline No & $785(90)$ & & 1 & \\
\hline Yes & $87(9.9)$ & & $1.6(0.9-1.8)$ & 0.09 \\
\hline \multicolumn{5}{|l|}{ Prison history } \\
\hline \multicolumn{5}{|l|}{ Previous incarceration } \\
\hline No & $372(42.6)$ & & 1 & \\
\hline Yes & $493(56.5)$ & 7 & $1.2(1.1-1.7)$ & 0.03 \\
\hline Time in prison, months, mean $\pm S D$ & $17 \pm 24$ & & & \\
\hline Number of individuals in lockup & $142(16.2)$ & & & \\
\hline$<26$ & & & 1 & \\
\hline $26-50$ & & & $2.3(1.2-5.2)$ & $<0.001$ \\
\hline Penal institution ${ }^{* *}$ & & & & 0.8 \\
\hline EPFCAJG & $26(2.9)$ & & & \\
\hline EPFTL & $18(2)$ & & & \\
\hline
\end{tabular}




\begin{tabular}{ll} 
EPFPP & $22(2.5)$ \\
EPFII & $74(8.5)$ \\
EPC & $87(10)$ \\
PTL & $72(8.2)$ \\
EPRB & $78(8.9)$ \\
CTAL & $34(3.9)$ \\
PTCG & $159(18.2)$ \\
IPCG & $83(9.5)$ \\
EPJFC & $87(10)$ \\
PHAC & $132(15)$ \\
\hline
\end{tabular}

Here and below: Significant $\mathrm{p}$ values are in bold; IDU- injecting drug user, STI: sexually transmitted infection; *Presence of genital discharge in the last month;**See abbreviations in Figure 1.

Figure 2: Prevalence of HSV-2 positivity ${ }^{*}$ among male and female prisoners in different age groups.

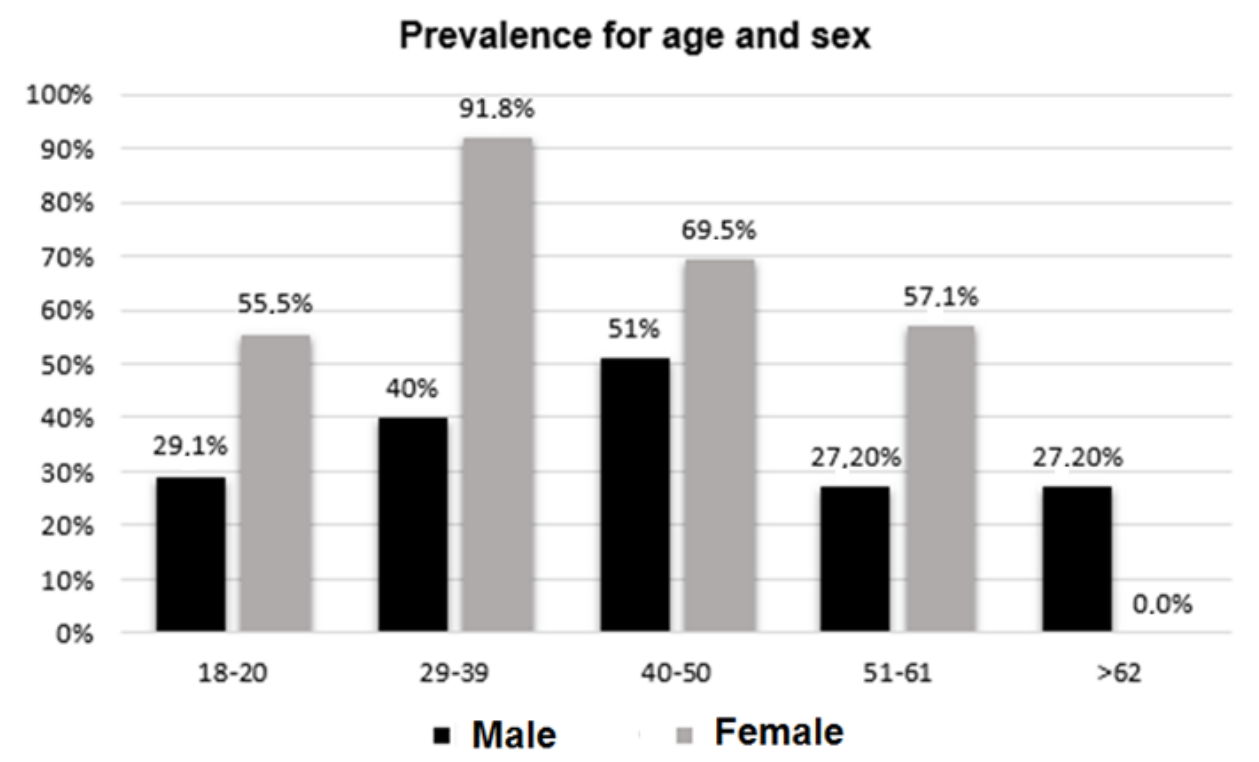

*Here and below: Presence of anti-HSV-2 IgG.

The multivariable model (Table 2), adjusted, indicated significant and

122 independent associations of HSV-2 positivity with female sex, age older than 18 to 29 years, unmarried status, history of an STI, no previous incarceration, being incarcerated

124 with more than 26 others, presence of genital discharge, previous homosexual intercourse, 
125 HIV-positivity, and no use/occasional use of condoms during sexual intercourse ( $\mathrm{p}<0.01$

126 for all comparisons).

Table 2: Multivariate analysis of factors associated with HSV-2 positivity*.

\begin{tabular}{|c|c|c|c|c|}
\hline \multirow[b]{2}{*}{ Variable } & \multicolumn{3}{|c|}{ HSV-2 positivity $(n=376)$} & \multirow[b]{2}{*}{ p-value } \\
\hline & n (\%) & Prevalence $(\%)$ & aOR $(95 \% \mathrm{CI})$ & \\
\hline \multicolumn{5}{|l|}{ Sex } \\
\hline Male & $732(83.9)$ & $280(32.1)$ & 1 & \\
\hline Female & $140(16.1)$ & $96(11)$ & $3.4(2.3-5.0)$ & $<0.001$ \\
\hline \multicolumn{5}{|l|}{ Age group (years) } \\
\hline $18-29$ & & & 1 & \\
\hline 29-39 & $301(34.5)$ & $141(16.1)$ & $1.8(1.2-2.8)$ & 0.001 \\
\hline $40-50$ & $123(14.1)$ & $67(7.6)$ & $2,7(1.6-4.6)$ & $<0.001$ \\
\hline $51-61$ & $39(4.4)$ & $23(28)$ & $2.6(1.1-6.0)$ & 0.02 \\
\hline \multicolumn{5}{|l|}{ Marital status } \\
\hline Married & & & 1 & \\
\hline Not married & 347 (39.7) & 137 (15.7) & $1.8(1.1-3.1)$ & 0.02 \\
\hline \multicolumn{5}{|l|}{ History of STI(s) } \\
\hline No & & & 1 & \\
\hline Yes & $19(2.1)$ & $11(1.2)$ & $4.9(1.7-13.5)$ & 0.002 \\
\hline \multicolumn{5}{|c|}{ Previous incarceration } \\
\hline Yes & & & 1 & \\
\hline No & $373(42.7)$ & $163(18.6)$ & $1.5(1.1-2.1)$ & 0.01 \\
\hline \multicolumn{5}{|c|}{ Number of individuals in lockup } \\
\hline$<26$ & & & 1 & \\
\hline $26-50$ & $142(16.2)$ & $54(6.1)$ & $1.8(1.2-2.7)$ & $<0.001$ \\
\hline \multicolumn{5}{|c|}{ Genital discharge ${ }^{* *}$} \\
\hline No & & & 1 & \\
\hline Yes & $87(9.9)$ & $53(6)$ & $4.8(2.5-6.6)$ & $<0.001$ \\
\hline \multicolumn{5}{|c|}{$\begin{array}{l}\text { Previously homosexual } \\
\text { intercourse }\end{array}$} \\
\hline No & & & 1 & \\
\hline Yes & $69(7.9)$ & $25(2.8)$ & $1.9(1.1-3.3)$ & 0.01 \\
\hline \multicolumn{5}{|l|}{ HIV status } \\
\hline Negative & & & 1 & \\
\hline Positive & $9(1)$ & $6(0.6)$ & $5.4(3.1-9.8)$ & 0.01 \\
\hline \multicolumn{5}{|l|}{ Condom use } \\
\hline Always & & & 1 & \\
\hline Sometimes/never & $242(27.7)$ & $117(13.4)$ & $1.9(1.2-2.9)$ & 0.001 \\
\hline
\end{tabular}

We further analyzed patients with active HSV-2 infections, based on anti-HSV-2

128 IgM positivity (Table 3). The results of this multivariable analysis which adjusted for the

129 same factors in Table 2 indicated that non-married status $(\mathrm{aOR}=2.6,95 \% \mathrm{CI}=1.03$ to 

to 7.2) were significantly associated with active HSV-2 infection.

Table 3: Multivariable analysis of factors associated with the presence of active HSV-2 infection* ( $\mathrm{n}=85)$ among those who were positive for anti-HSV-2 IgG $(\mathrm{n}=184)$.

\begin{tabular}{lcc}
\hline Variable & aOR $(\mathbf{9 5 \%}$ CI $)$ & p-value \\
\hline Marital status & 1 & \\
Married & $2.6(1.03-6.5)$ & $\mathbf{0 . 0 1}$ \\
Not married & & \\
Number of individuals in lockup & 1 & \\
$<26$ & $2.9(1.2-7.2)$ & $\mathbf{0 . 0 1}$ \\
$26-50$ &
\end{tabular}

*presence of anti-HSV-2 IgM.

132

\section{Discussion}

The present study is the first epidemiological study of the seroprevalence of HSV-2 in prisoners at penal establishments of Brazil.

Our results have several important implications for public health. First, the overall prevalence of HSV-2 infection was $43.1 \%$, almost four-times higher than the global prevalence $(11.3 \% ;[16,18]$, and also higher than the prevalence in the general population of Brazil (about 30\%; [19]. The prevalence of HSV-2 infection in this study was also higher than reported in previous studies of prisoners elsewhere in the world. For example, the seroprevalence was $20.5 \%$ at prisons in northern Italy, $21.3 \%$ at prisons in southern Italy [20], 19.9\% in a cross-sectional regional level study of prisons in Portugal [21], and $14.5 \%$ at prisons in Nigeria [22].

The higher prevalence of HSV-2 infection in Brazil may be due to the ineffectiveness of its prison organization, in which incarceration can directly and indirectly cause adverse health effects [3].

We also found that the estimated prevalence of HSV-2 infection was greater in female $(68 \%)$ than male (37\%) prisoners. Statistical analysis indicated the prevalence was 
3.4-fold greater in women (95\% CI $=2.3$ to 5.0). A similar study in Australia [23] also reported that women had a higher seroprevalence rate for HSV-2 than men. This may be because the signs and symptoms in women occur in the vaginal mucosa, and therefore tend to be less visible $[24,25]$; [26]. In addition, the sexual transmission of herpes from men to women is much more efficient than the transmission from women to men $[12,27$, 28]. Furthermore, HSV-2 can be transmitted to the fetus during pregnancy and delivery $[24,25]$.

Our results indicated that the risk for HSV-2 increased with age (age 29 to 39 years: $\mathrm{aOR}=1.8,95 \% \mathrm{CI}=1.2$ to 2.8 ; age 40 to 50 years: $\mathrm{aOR}=2.7,95 \% \mathrm{CI}=1.6$ to 4.6; age 51 to 61 years: $\mathrm{aOR}=2.6,95 \% \mathrm{CI}=1.1$ to 6.0 ). This may be because those who are older simply have more years during which they could possibly be exposed.

Our results indicated that prisoners who already had another STI had a nearly 5fold increased risk of $\mathrm{HSV}-2$ positivity $(95 \% \mathrm{CI}=1.7$ to 13.5$)$. A cohort study of prisoners in Nigeria reported the risk of HSV-2 positivity was 30-fold higher for those with another STI $(95 \% \mathrm{CI}=11.3$ to 82.3$)$ [22]. A study of prisoners in the United States reported that those with HSV-2 infections had an up to 3-fold increased risk of other transmissible STIs, including HIV [29]; this study also found that HIV seropositivity was associated with a 5-fold increased risk for HSV-2 infection (95\% CI = 3.1 to 9.8). A 2017 study by our group found that the prevalence of HSV-2 in HIV-positive pregnant women was 3fold greater than the prevalence of HIV-negative pregnant women [30].

The present study also showed that prisoners who were not previously incarcerated had an increased risk of HSV-2 positivity relative to those who were previously incarcerated ( $\mathrm{aOR}=1.5,95 \% \mathrm{CI}=1.1$ to 2.1$)$ and that the presence of 26 or more other prisoners in the same cell increased the risk of HSV-2 positivity (aOR $=1.8$, $95 \% \mathrm{CI}=1.2$ to 2.7$)$. None of our study participants reported apparent lesions from HSV- 
1732 infections, however the presence of genital discharge in the last month increased the 174 risk for HSV-2 positivity, even though HSV-2 infection is typically characterized by no 175 apparent signs or symptoms. The most common symptoms of infection are vaginal 176 discharge and/or discomfort during sexual relations [31].

Although our prisoners reported a low frequency of homosexual intercourse (7.9\%), individuals who did have homosexual intercourse had an increased risk of HSV2 positivity $(\mathrm{aOR}=1.9,95 \% \mathrm{CI}=1.1$ to 3.3$)$. Many previous studies have examined HSV-2 in populations of men who have sex with men. The results indicated a high prevalence in this population, thus demonstrating the importance of implementing prevention programs that target these high-risk groups [32]; [33]; [34]; [35]. anti-HSV-2 IgG-positive. However, the presence of this IgM does not necessarily suggest a primary infection, because reactivation of a latent infection may lead to anti-HSV-2 $\operatorname{IgM}$ positivity [36]. We also found that the presence of more prisoners in the same cell $(<26$ vs. 26 to 50$)$ is associated with an increased risk of active HSV-2 infection $(\mathrm{aOR}=$ $2.9,95 \% \mathrm{CI}=1.2$ to 7.2 ). This is likely because overcrowding increases contact among prisoners, and is also associated with more intimate contact and worse hygiene.

Conflict in the prison environment can adversely impact the health of prisoners, and ultimately impact society at large by contributing to the spread of multiple STIs. This is because there is significant mobility into and out of prisons, with about 30 million people transiting each year worldwide there is also great mobility within individual prisons, due to transfers among different units, and the return of former prisoners who committed subsequent crimes [37]. Thus, the high rate of HSV-2 infection at prisons in 
197 interventions are necessary because the cost of prevention is much lower than the cost of

198

199

200

201

202

203

204

205

206

207

208

209

210

211

212 treatment $[38,39]$.

This study had some limitations. First, the reported associations rely upon the veracity and memory of the study participants', especially regarding risky behaviors.

\section{Conclusions}

This could lead to biases in the relationships of different study variables with HSV-2 infection. Moreover, the rarity of previous studies on this topic and of data on HSV-2 in prison populations worldwide make it difficult to compare our results with those of prisoners in other geographic areas. This emphasizes the urgent need for more studies of STIs in prison populations.

The results of our study indicate there is an urgent need to implement effective health education strategies in Brazilian prisons. In particular, there is a need to improve preventive measures, provide appropriate care for individuals with STIs, and reduce the conditions of overcrowding, high stress, and exposure to illicit drugs. Serological screening at the time of confinement may be a simple but effective intervention. 


\author{
Abbreviations \\ HSV-2- Herpes virus 2; \\ STIs- Sexually transmitted infections; \\ IgG- Immunoglobulin of glycoprotein G; \\ IgM- Immunoglobulin of glycoprotein M; \\ HIV- human immunodeficiency virus; \\ WHO- World Health Organization; \\ CE- Ethics Committee (initials in Portuguese); \\ UFGD- Federal University of Grande Dourados (initials in Portuguese); \\ CAAE- Presentation certificate for Ethical Appreciation (initials in Portuguese); \\ MS- Mato Grosso of Sul; \\ Agepen- State Agency of Administration of the Penitentiary System (initials in \\ Portuguese); \\ ICF- informed consent form; \\ EPFCAJG, women's penal establishment Carlos Alberto Jonas Giordano; \\ EPFTL, women's penal establishment Três Lagoas; \\ EPFPP- women's penal establishment Ponta Porã; \\ EPFIIZE- women's penal establishment Irmã Irma Zorzi; \\ EPC- penal establishment de Corumba; PTL, penal establishment Três Lagoas; \\ EPRB- penal establishment Ricardo Brandão; \\ CTAL- Centro de Triagem Anoazio Lima; \\ PTCG- penal establishment de Campo Grande; \\ IPCG- penal establishment Campo Grande; \\ EPJFC- penal establishment Jair Ferreira de Carvalho; \\ PHAC- penal establishment Harry Amorim Costa; \\ pValue- Probability of obtaining the observed results of a test; \\ ORs- An odds ratio is a statistic that quantifies the strength of the association between \\ two events; \\ IDU- injecting drug user; \\ SD- Standard deviation (SD) measures the amount of variability, or dispersion, for a \\ subject set of data from the mean; \\ aOR- Odds Ratio adjusted by logistic regression; \\ CI- Confidence interval;
}




\section{Declarations}

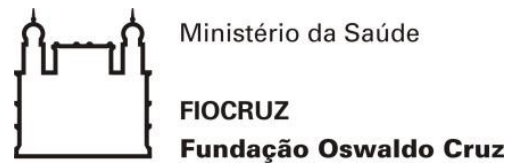

$17^{\text {th }}$ January, 2020

\section{Ethics approval and consent to participate}

Dear Editor for BMC Infectious Diseases,

Please find enclosed our manuscript entitled "HIGH PREVALENCE OF ALPHAHERPES VIRUS 2 (HSV-2) POSITIVITY IN PRISONS FROM MIDWEST BRAZIL: A CROSS-SECTIONAL STUDY”

This study was approved by the Education and Training Unit of the Federal University of Grande Dourados (CE/UFGD) CAAE number: 05598912.0.0000.5160 opinion 191.877 in 26th January, 2013 and the State Agency of Administration of the Penitentiary System/MS (Agepen/MS). The participants were approached and asked to sign an informed consent form (ICF) which explained the purpose of the study. Emphasis was placed on the confidentiality of each individual's identity and personal information by explaining that only the team of researchers would have access to the information, and that all data would be used exclusively for research purposes.

These documents are below for consultation.

Sincerely yours,

Vanessa de Paula, Ph.D. 


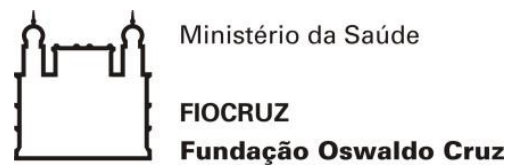

$17^{\text {th }}$ January, 2020

\section{Availability of data and materials}

Dear Editor for BMC Infectious Diseases,

Please find enclosed our manuscript entitled "HIGH PREVALENCE OF ALPHAHERPES VIRUS 2 (HSV-2) POSITIVITY IN PRISONS FROM MIDWEST BRAZIL: A CROSS-SECTIONAL STUDY" by Nathália Alves Araujo de Almeida, Lyana Rodrigues Pinto Lima, Marco Antonio Moreira Puga, Ana Rita Coimbra Motta de Castro, Marco Aurelio Horta and Vanessa Salete de Paula. This study has a population with disabilities and difficult access and therefore releases research data from research is not applicable, however the data that support the findings of this study are available from [Puga et al, 2017] but restrictions apply to the availability of these data, which were used under license for the current study, and so are not publicly available. Data are however available from the authors upon reasonable request and with permission of [Julio Croda, Director of the Communicable Disease Surveillance Department at the Ministry of Health's Health Surveillance Secretariat and Ana Rita Coimbra Motta de Castro, public health researcher responsible for collection].

I'm sorry I can't share the data, we sincerely hope our manuscript is acceptable for publication and look forward to your reply.

Sincerely yours,

Vanessa de Paula, Ph.D.

Oswaldo Cruz Foundation - Virology

Av. Brasil 4365, 21040-360, Rio de Janeiro, Brazil

Tel: 55212598 1823;

Email: vdepaula@ioc.fiocruz.br 


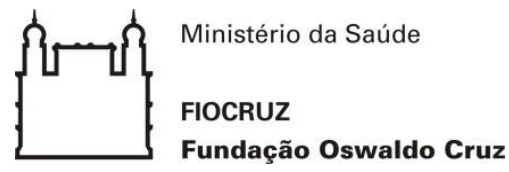

$17^{\text {th }}$ January, 2020

\section{Competing interests}

Dear Editor for BMC Infectious Diseases,

Please find enclosed our manuscript entitled "HIGH PREVALENCE OF ALPHAHERPES VIRUS 2 (HSV-2) POSITIVITY IN PRISONS FROM MIDWEST BRAZIL: A CROSS-SECTIONAL STUDY"

I declare for due purposes that this publication does not contain financial and / or non-financial interests.

I am available for further additional clarification.

Sincerely yours,

Vanessa de Paula, Ph.D.

Oswaldo Cruz Foundation - Virology

Av. Brasil 4365, 21040-360, Rio de Janeiro, Brazil

Tel: 55212598 1823;

Email:vdepaula@ioc.fiocruz.br 


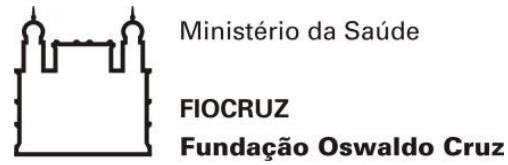

$17^{\text {th }}$ January, 2020

\section{Declaration of Funding}

Dear Editor for BMC Infectious Diseases,

Please find enclosed our manuscript entitled "HIGH PREVALENCE OF ALPHAHERPES VIRUS 2 (HSV-2) POSITIVITY IN PRISONS FROM MIDWEST BRAZIL: A CROSS-SECTIONAL STUDY"

I declare that for the development of the research we have public funding from CNPQ (Scientific and Technological Development) and CAPES (Higher Education Personnel Improvement Coordination) Ministry of Health and Ministry of Education in Brazil. These investments range from the payment of the professionals involved to the purchase of inputs for laboratory tests.

I am available for further additional clarification.

Sincerely yours,

\section{Vanessa de Paula, Ph.D.}

Oswaldo Cruz Foundation - Virology

Av. Brasil 4365, 21040-360, Rio de Janeiro, Brazil

Tel: 55212598 1823;

Email:vdepaula@ioc.fiocruz.br 


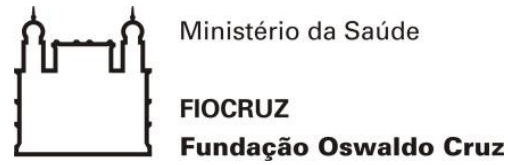

\section{Authors' contributions}

Dear Editor for BMC Infectious Diseases,

Please find enclosed our manuscript entitled "HIGH PREVALENCE OF ALPHAHERPES VIRUS 2 (HSV-2) POSITIVITY IN PRISONS FROM MIDWEST BRAZIL: A CROSS-SECTIONAL STUDY” All authors of the manuscript worked for the work to be successfully completed, below is the role of each author.

NAAA- Responsible for the master's thesis defended in 2019, he performed all diagnostic tests and manuscript writing.

LRPL- Responsible for processing samples and assisting in diagnostic tests.

MAMP- Responsible for filling the entire database of participants.

AR-Study coordinator responsible for sample collection and data processing.

MH -Responsible for statistical analysis.

VSP- manager of the laboratory in which the research was conducted, responsible for writing and developing the study and the manuscript.

All authors have read and agree with the submission of the manuscript

I am available for further additional clarification.

Sincerely yours,

Vanessa de Paula, Ph.D. 


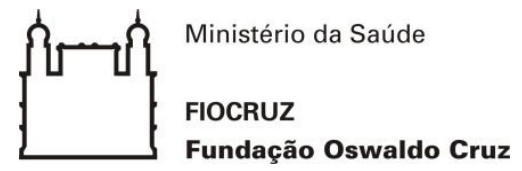

\section{Acknowledgements}

Dear Editor for BMC Infectious Diseases,

Please find enclosed our manuscript entitled "HIGH PREVALENCE OF ALPHAHERPES VIRUS 2 (HSV-2) POSITIVITY IN PRISONS FROM MIDWEST BRAZIL: A CROSS-SECTIONAL STUDY”

I would like to thank the research PARTICIPANTS who voluntarily accepted contributed to this work.

To Dr. JULIO CRODA and all his TEAM, for their commitment and courage in carrying out the collections.

To all the DIRECTORS responsible for the criminal institutions that allowed the work to be carried out.

Sincerely

Vanessa de Paula, Ph.D. 


\section{References}

1. $\quad$ Lynch JP, Lynch JP, Sabol WJ: Prisoner Reentry in Perspective. 2001.

2. Puga MA, Bandeira LM, Pompilio MA, Croda J, Rezende GR, Dorisbor LF, Tanaka TS, Cesar GA, Teles SA, Simionatto $\mathrm{S}$ et al: Prevalence and Incidence of HCV Infection among Prisoners in Central Brazil. PLoS One 2017, 12(1):e0169195.

3. Minayo MC, Ribeiro AP: Health conditions of prisoners in the state of Rio de Janeiro, Brazil. Cien Saude Colet 2016, 21(7):2031-2040.

4. Crofts N, Cooper G, Stewart T, Kiely P, Coghlan P, Hearne P, Hocking J: Exposure to hepatitis A virus among blood donors, injecting drug users and prison entrants in Victoria. $J$ Viral Hepat 1997, 4(5):333-338.

5. Levy M, Johnson CG, Kraa E: Tonsillopharyngitis caused by foodborne group A streptococcus: a prison-based outbreak. Clin Infect Dis 2003, 36(2):175-182.

6. World Prison Brief | an online database comprising information on prisons and the use of imprisonment around the world [http://www.prisonstudies.org/]

7. Roizman B, Whitley RJ: The nine ages of herpes simplex virus. Herpes 2001, 8(1):23-27.

8. Grinde B: Herpesviruses: latency and reactivation - viral strategies and host response. In: $J$ Oral Microbiol. Volume 5, edn.; 2013.

9. Kimberlin DW: Herpes simplex virus infections of the central nervous system. Semin Pediatr Infect Dis 2003, 14(2):83-89.

10. Schomogyi M, Wald A, Corey L: Herpes simplex virus-2 infection. An emerging disease? Infect Dis Clin North Am 1998, 12(1):47-61.

11. Bettahi I, Zhang X, Afifi RE, BenMohamed L: Protective immunity to genital herpes simplex virus type 1 and type 2 provided by self-adjuvanting lipopeptides that drive dendritic cell maturation and elicit a polarized Th1 immune response. Viral Immunol 2006, 19(2):220-236.

12. Xu F, Sternberg MR, Kottiri BJ, McQuillan GM, Lee FK, Nahmias AJ, Berman SM, Markowitz LE: Trends in herpes simplex virus type 1 and type 2 seroprevalence in the United States. Jama 2006, 296(8):964-973.

13. Morrison LA: Replication-defective virus vaccine-induced protection of mice from genital herpes simplex virus 2 requires CD4 T cells. Virology 2008, 376(1):205-210.

14. Vagvala SP, Thebeau LG, Wilson SR, Morrison LA: Virus-encoded b7-2 costimulation molecules enhance the protective capacity of a replication-defective herpes simplex virus type 2 vaccine in immunocompetent mice. $J$ Virol 2009, 83(2):953-960.

15. Chentoufi AA, Benmohamed L: Mucosal herpes immunity and immunopathology to ocular and genital herpes simplex virus infections. Clin Dev Immunol 2012, 2012:149135.

16. Looker KJ, Magaret AS, May MT, Turner KM, Vickerman P, Gottlieb SL, Newman LM: Global and Regional Estimates of Prevalent and Incident Herpes Simplex Virus Type 1 Infections in 2012. PLoS One 2015, 10(10): 0140765.

17. Penello AM, Campos, B.C., Simão, M.: Herpes genital. J Bras Doenas Sex Transm 2010, 22(2):64-72.

18. Olsson J, Kok E, Adolfsson R, Lovheim H, Elgh F: Herpes virus seroepidemiology in the adult Swedish population. Immun Ageing 2017, 14:10.

19. Clemens SA, Farhat CK: Seroprevalence of herpes simplex 1-2 antibodies in Brazil. Rev Saude Publica 2010, 44(4):726-734.

20. Sarmati L, Babudieri S, Longo B, Starnini G, Carbonara S, Monarca R, Buonomini AR, Dori L, Rezza G, Andreoni M: Human herpesvirus 8 and human herpesvirus 2 infections in prison population. J Med Virol 2007, 79(2):167-173.

21. Marques NM, Margalho R, Melo MJ, Cunha JG, Melico-Silvestre AA: Seroepidemiological survey of transmissible infectious diseases in a portuguese prison establishment. Braz J Infect Dis 2011, 15(3):272-275.

22. Ibrahim A: Seroepidemiology of Herpes Simplex Virus Type-2 (HSV-2) Among Incarcerated Population of Potiskum Medium Security Prison Potiskum Yobe State: Study of Prevalence and Associated Risk Factors. IntJCurrMicrobiolAppSci 2015, 4:632-637.

23. Simpson PL, Reekie J, Butler TG, Richters J, Yap L, Grant L, Richards A, Donovan B: Factors Associated With Sexual Coercion in a Representative Sample of Men in Australian Prisons. Arch Sex Behav 2016, 45(5):1195-1205.

24. Brown ZA, Benedetti J, Ashley R, Burchett S, Selke S, Berry S, Vontver LA, Corey L: Neonatal Herpes Simplex Virus Infection in Relation to Asymptomatic Maternal Infection at the Time of Labor. http://dxdoiorg/101056/NEJM199105023241804 2010. 
25. Hollier LM, Wendel GD: Third trimester antiviral prophylaxis for preventing maternal genital herpes simplex virus (HSV) recurrences and neonatal infection. 2017.

26. Kaul R, Nagelkerke NJ, Kimani J, Ngugi E, Bwayo JJ, Macdonald KS, Rebbaprgada A, Fonck K, Temmerman M, Ronald AR et al: Prevalent herpes simplex virus type 2 infection is associated with altered vaginal flora and an increased susceptibility to multiple sexually transmitted infections. J Infect Dis 2007, 196(11):1692-1697.

27. Langenberg AG, Corey L, Ashley RL, Leong WP, Straus SE: A prospective study of new infections with herpes simplex virus type 1 and type 2. Chiron HSV Vaccine Study Group. N Engl J Med 1999, 341(19):1432-1438.

28. Clemens SAC, Instituto de Pós-Graduação Médica Carlos Chagas RdJ, Brasil, Universidade Federal de São Paulo SP, Brasil, Farhat CK, Universidade Federal de São Paulo SP, Brasil: Seroprevalence of herpes simplex 1-2 antibodies in Brazil. Rev Saúde Pública 2010, 44(4):726734.

29. Altice FL, Marinovich A, Khoshnood K, Blankenship KM, Springer SA, Selwyn PA: Correlates of HIV infection among incarcerated women: implications for improving detection of HIV infection. J Urban Health 2005, 82(2):312-326.

30. Lima LRP, Fernandes L, Villela DAM, Morgado MG, Pilotto JH, de Paula VS: Co-infection of human herpesvirus type 2 (HHV-2) and human immunodeficiency virus (HIV) among pregnant women in Rio de Janeiro, Brazil. AIDS Care 2018, 30(3):378-382.

31. Groves MJ: Genital Herpes: A Review. Am Fam Physician 2016, 93(11):928-934.

32. Rodrigues J, Grinsztejn B, Bastos FI, Velasque L, Luz PM, de Souza CT, Georg I, Pilotto JH, Veloso VG: Seroprevalence and factors associated with herpes simplex virus type $\mathbf{2}$ among HIV-negative high-risk men who have sex with men from Rio de Janeiro, Brazil: a crosssectional study. BMC Infect Dis 2009, 9:39.

33. Silva AdSd, Lima LRP, Perse AdS, Castro LS, Rezende GRd, Pires FR, Puga MAM, Bandeira LM, Tanaka TSO, Motta-Castro ARC et al: Epidemiological evaluation of herpes simplex virus in men who have sex with men in Mato Grosso do Sul, Brazil. 2015.

34. Thienkrua W, Todd CS, Chonwattana W, Wimonsate W, Chaikummao S, Varangrat A, Chitwarakorn A, van Griensven F, Holtz TH: Incidence of and temporal relationships between HIV, herpes simplex II virus, and syphilis among men who have sex with men in Bangkok, Thailand: an observational cohort. In: BMC Infect Dis. Volume 16, edn.; 2016.

35. Vergara-Ortega DN, Sevilla-Reyes EE, Herrera-Ortiz A, Torres-Ibarra L, Salmeron J, LazcanoPonce E, Sanchez-Aleman MA: Real time PCR to evaluate HSV-2 shedding from anal and genital samples among men who have sex with men, living with HIV. J Med Virol 2018, 90(4):745-752.

36. Tada DG, Khandelwal N: Serum HSV-1 and 2 IgM in Sexually Transmitted Diseases - More for Screening Less for Diagnosis: An Evaluation of Clinical Manifestation. J Glob Infect Dis 2012, 4(3):S1-4.

37. Zachariah R, Massaquoi M: Cotrimoxazole prophylaxis for HIV-positive TB patients in developing countries. - PubMed - NCBI. Trop Doct 2006, 36(2):79-82.

38. Sousa KAAd, Universidade Federal do Piauí T, Brasil, Universidade Federal do Piauí T, Brasil, Araújo TMEd, Universidade Federal do Piauí T, Brasil, Universidade Federal do Piauí T, Brasil, Teles SA, Universidade Federal de Goiás G, Brasil, Universidade Federal de Goiás G, Brasil, Rangel EML et al: Factors associated with HIV prevalence in a prison population. Rev esc enferm USP 2017, 51.

39. Arruda AJCG de VDd, Silva CC da et al: HEALTH WHILE A RIGHT OF PRISONERS AND THE PRISON SYSTEM SUB JUDICE ORIGINAL ARTICLE. 2017. 


\section{Figures}

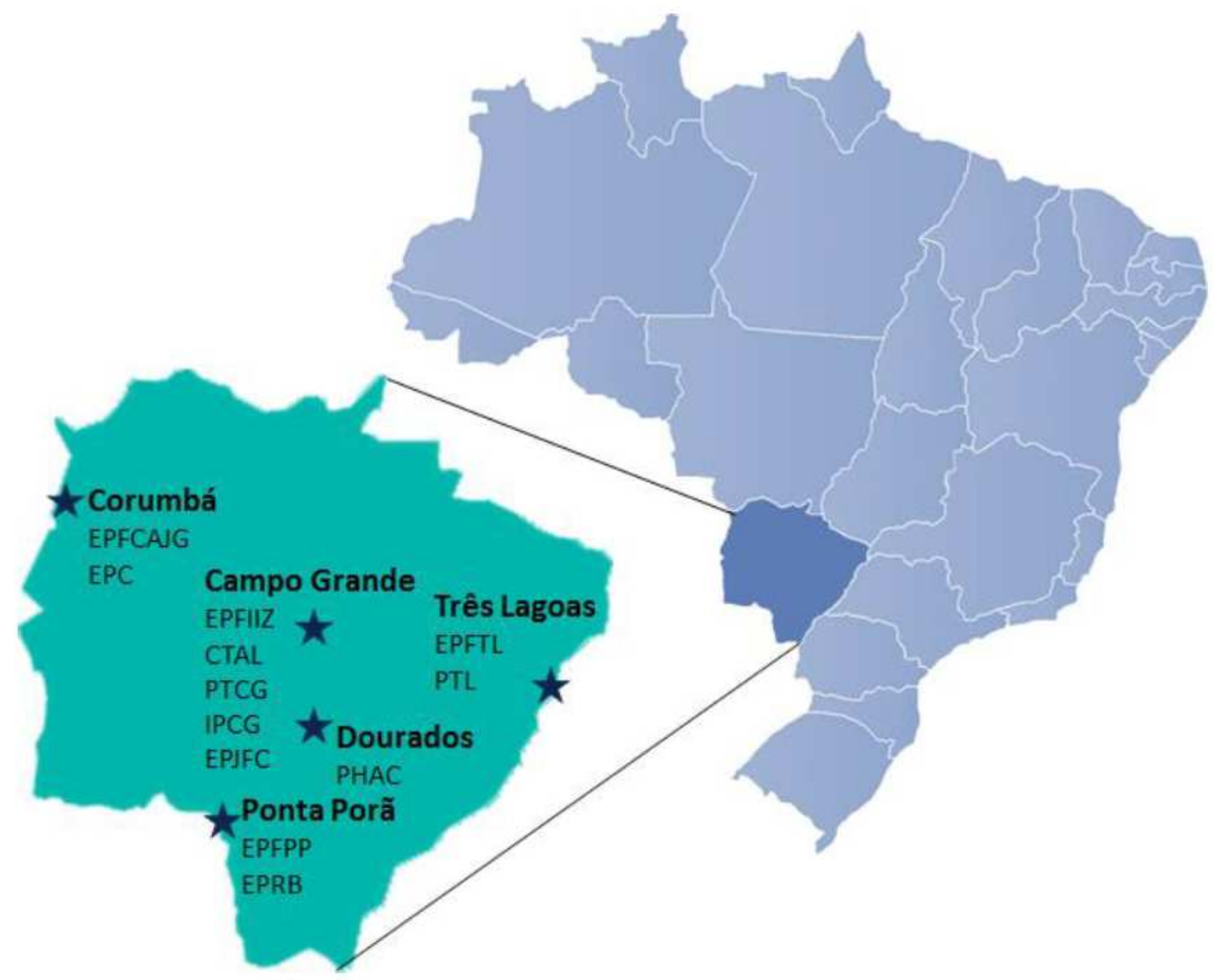

Figure 1

Locations of the 12 study prisons in the state of Mato Grosso do Sul, Brazil . Abbreviations: EPFCAJG, women's penal establishment Carlos Alberto Jonas Giordano; EPFTL, women's penal establishment Três Lagoas; EPFPP, women's penal establishment Ponta Porã; EPFIIZE, women's penal establishment Irmã Irma Zorzi; EPC, penal establishment de Corumba; PTL, penal establishment Três Lagoas; EPRB, penal establishment Ricardo Brandão; CTAL, Centro de Triagem Anoazio Lima; PTCG, penal establishment de Campo Grande; IPCG, penal establishment Campo Grande; EPJFC, penal establishment Jair Ferreira de Carvalho; PHAC, penal establishment Harry Amorim Costa. 


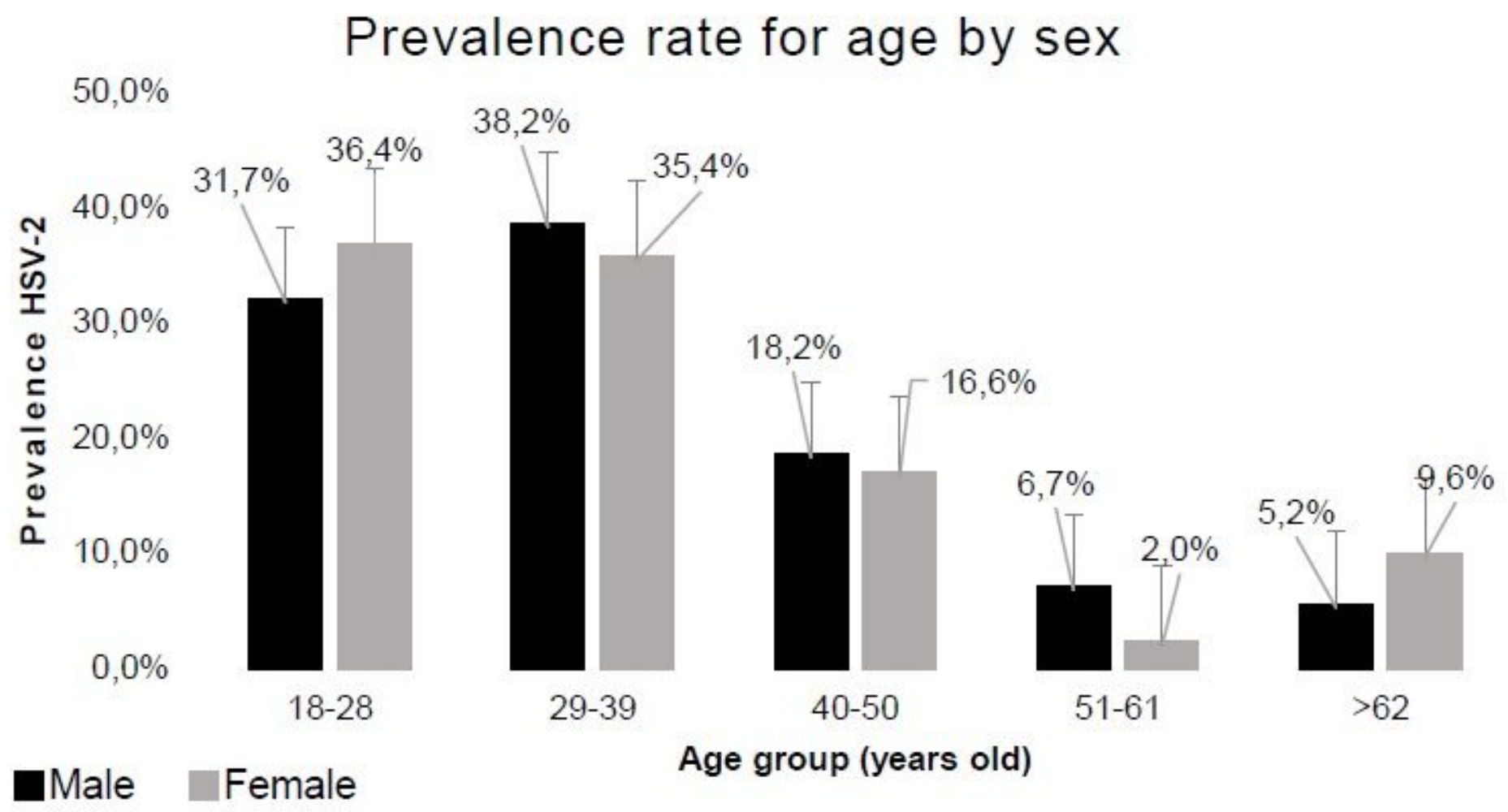

Figure 2

Prevalence of HSV-2 positivity* among male and female prisoners in by age groups. *Here and below. The denominator was the total number of positive HSV-2 IgG participants by sex (males $=280$; females = 96).

\section{Supplementary Files}

This is a list of supplementary files associated with this preprint. Click to download.

- STROBEok.docx 